\title{
PROMOTION OF INVESTMENT IN MICRO INSURANCE POLICY A STUDY WITH REFERENCE TO KOLLAM DISTRICT KERALA
}

\author{
R. Neelamegam \\ Department of Management Studies, Virudhunagar Hindu Nadars' Senthikumara Nadar College, India
}

\begin{abstract}
The development of micro insurance in India not only depends on the product scheme and delivery system but also on generating the appropriate sub structure and motivating the performance of insurance agents. It is essential for programming the banks as significant delivery network for micro insurance and the banks could drive the process for the growth of the insurance in the rural. Currently, various NGOs and MFIs are also providing micro insurance policies apart from private and public insurance companies, whatever be the delivery system of micro insurance contact with potential clients or existing clients is necessary for the easy marketing of the policy and this is possible only by strengthening the existing agency force. The present paper examines the ways and means for improving investment in micro insurance policy with reference to Kollam district, Kerala State.
\end{abstract}

Keywords:

Micro Insurance, Insurance Agent, Means for Improving Investment in the Policy

\section{INTRODUCTION}

Insurance is a device for sharing of risks. As insurance is a cooperative device, a large number of persons share loss arising from a particular risk. The primary functions of insurance are provision of certainly of payment at the time of loss and make a share in the loss arising from the risk. Micro insurance refers to the insurance to the low income people. Micro insurance is a low value product involving modest premium and benefit package. Micro insurance requires different design and distribution strategy.

In regard to micro insurance players in the Indian Insurance market, it is essential to pursue the objectives in a more liberalized market scenario. The key objectives are the spread of micro insurance awareness among the prospective buyers, increasing the level of insurance penetration and meeting rural and social obligations.

\subsection{PROBLEM STATEMENT}

Micro insurance concept is a new one. As the micro insurance policy provides cover to low income people who are left with limited resources, there is a problem in persuading the potential clients to subscribe to the policy. The present paper explores ways and means for improving the investment in micro insurance policy in Kollam district, Kerala.

\subsection{OBJECTIVES OF STUDY}

- To identify suitable measures for raising the investment in micro insurance (life) policy in Kollam district, Kerala.

- To find out reasons for policyholders' intention to switch over to other insurance companies.

\subsection{HYPOTHESIS}

$H_{0}$ : The number of policyholders of insurance agents is not a function of method of accepting complaints, number of marketing training, policy knowledge training and periodical training attended by the agents. The format of test hypothesis is estimated as,

$$
Y=a+b_{1} x_{1}+b_{2} x_{2}, \ldots, b_{n} x_{n}+e
$$

The present study is restricted to micro (life) insurance policy.

\section{REVIEW OF LITERATURE}

Ito and Kono [1] observed that there are common problems associated with micro insurance such as low take - up rate, high claim rate and low renewal rate. Majumdar [2] in his paper highlights the buying behavior of life insurance in India, reasons for low penetration and what the insurers can do to raise insurance penetration. Shah and Dixit [3] conceptualize that the penetration of rural insurance in India requires a fresh approach to sell rural insurance products. Murali [4] says that there are some strange insurance products in the global insurance market beyond the routine covers that one has got to see more regularly. Reddy [5] reports that micro insurance is quite different from other low income insurance products available in the market. It's time for all insurance companies to remodel the micro insurance products and target poor people for covering under micro insurance with more financial services. Jeyaseelam [6] says that insurance should modify the micro insurance products to diverse market segments. As the micro insurance sector is in its childhood, all the stakeholders have to put in their intensive effort in building the sector.

\section{DATA AND METHODOLOGY}

Survey technique was used as the study mainly depended on primary data. Questionnaire was the data gathering instrument. The sample survey went on for nine months during the period 2016-2017. As per Kokeran formula sample size was determined as 400 policyholders. Stratified sampling was used for the selection of samples. Relevant statistical tools such as percentage calculation, mean, standard deviation, and dummy variable multiple regression were used for the analysis of survey data.

\subsection{ANALYTICAL MODEL}

The model of the study measuring the variable is shown in the following Fig.1. 


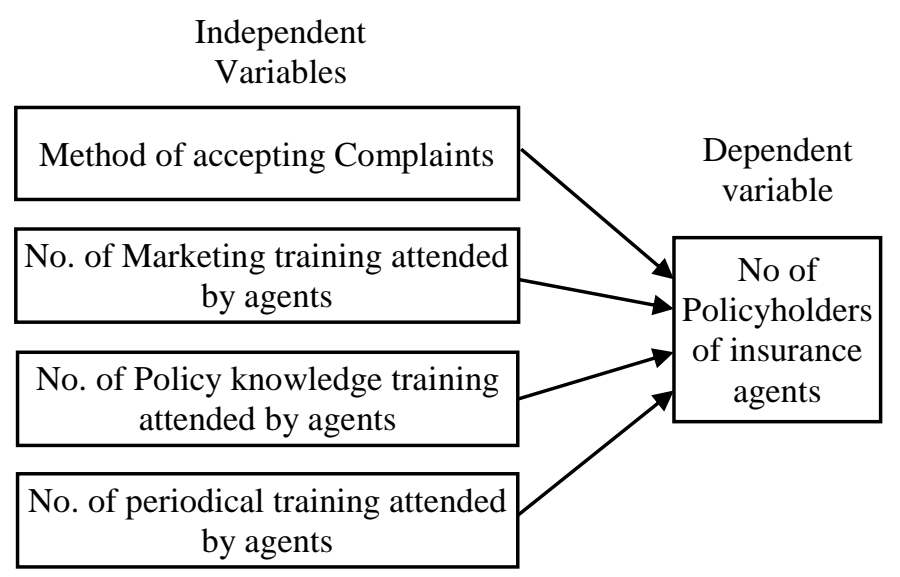

Fig.1. Analytical Model

\section{FINDINGS OF STUDY}

If the customers are skeptical of service quality, they would switch over to other companies. The survey noted the policyholders' intention to switch over to other insurance companies.

Table.1. Policyholders' intention to switch over

\begin{tabular}{|c|c|c|}
\hline Intention & F & \% to Total \\
\hline Will Switch over & 237 & 59.30 \\
\hline Will not switch over & 163 & 40.70 \\
\hline Total & 400 & 100.00 \\
\hline
\end{tabular}

Source: Primary data

A striking disclosure is that a majority of clients (59.3\%) would like to switch over to other companies if they are given an opportunity for it. Further delve into the matter has brought to surface the reasons for the switch over to other insurance companies.

It is evident from the above analysis that low amount of premium is the most important reason for the policyholders' intention to switch over to other insurance companies, followed by high risk coverage, better service of other insurance agents, and speedy redressal of clients' grievances in other companies.

\section{PERFORMANCE OF DUMMY VARIABLE MULTIPLE REGRESSION}

In order to find which of the variable are significant in causing variation in the number of policyholders of insurance agents, multiple regression was made. From the analysis it was found that gender, age, experience as LIC agents, area, number of times contacted a prospective buyer, amount of commission, incentives, method of accepting compliant from clients, redressal of grievances, and number of training attended for policy knowledge, consumer approach, premium collection periodical training and special training were the variables affecting the dependent variable, i.e., number of policyholders of insurance agents. In order to extract the most significant variables affecting the number of policyholders held by the agents, backward selection method was applied; the method eliminated 16 insignificant variables from the regression model, and retained 4 significant variables in the regression equation. The output of regression analysis is presented in the following tables.

Table.2. Reasons for switch over to other companies

\begin{tabular}{|l|c|c|c|}
\hline \multicolumn{1}{|c|}{ Reason } & Mean & SD & Rank \\
\hline Low Premium & 4.08 & 1.06 & 1 \\
\hline High risk Coverage & 3.57 & 0.94 & 2 \\
\hline Better Service of insurance agents & 3.48 & 1.11 & 3.5 \\
\hline Change for growth of the Organization & 3.48 & 1.14 & 3.5 \\
\hline Heavy advertisement & 3.16 & 1.20 & 9 \\
\hline Nearness of organization & 3.46 & 1.24 & 5.5 \\
\hline Sound infrastructure of organization & 3.03 & 3.56 & 10 \\
\hline Speedy redressal of clients' grievances & 3.46 & 1.28 & 5.5 \\
\hline $\begin{array}{l}\text { Prompt disbursal of policy amount on } \\
\text { maturity }\end{array}$ & 3.31 & 1.21 & 8 \\
\hline $\begin{array}{l}\text { Frequently organizing awareness } \\
\text { programmes }\end{array}$ & 3.42 & 1.33 & 7 \\
\hline
\end{tabular}

Source: Primary data

Table.3. Model summary of Initial and Final Regression

\begin{tabular}{|c|c|c|c|c|c|}
\hline Model & $\mathbf{R}$ & $\mathbf{R}_{2}$ & $\begin{array}{c}\text { Adjusted } \\
\mathbf{R}_{2}\end{array}$ & $\begin{array}{c}\text { Std. error of } \\
\text { the estimate }\end{array}$ & $\begin{array}{l}\text { Durbin } \\
\text { Watson }\end{array}$ \\
\hline 1 & 0.540 & 0.292 & 0.252 & 39.155 & \\
\hline 17 & 0.508 & 0.258 & 0.250 & 39.212 & 1.931 \\
\hline
\end{tabular}

Table.4. ANOVA of Initial and Final Regression models

\begin{tabular}{|c|c|c|c|c|c|c|}
\hline \multicolumn{2}{|c|}{ Model } & $\begin{array}{c}\text { Sum of } \\
\text { Squares }\end{array}$ & df & $\begin{array}{c}\text { Mean } \\
\text { square }\end{array}$ & F & Sig. \\
\hline \multirow{3}{*}{1} & Regression & 238709 & 21 & 11367.09 & 7.414 & 0.000 \\
\cline { 2 - 8 } & Residual & 579528.4 & 378 & 1533.14 & & \\
\cline { 2 - 8 } & Total & 818237.4 & 399 & & & \\
\hline \multirow{2}{*}{17} & Regression & 210904.4 & 4 & 52726.1 & 34.292 & 0.000 \\
\cline { 2 - 8 } & Residual & 607333 & 3954 & 1537.55 & & \\
\cline { 2 - 8 } & Total & 818237.4 & 399 & & & \\
\hline
\end{tabular}

The Table. 4 shows the significance levels of $F$ values of initial and final regression models are less than 0.05 , which indicate that the regression model is well fitted to the data and the models can be used for studying the variation of number of policyholders held by the agents in respect of the selected independent variables. 
Table.5. Coefficient of initial Regression Model

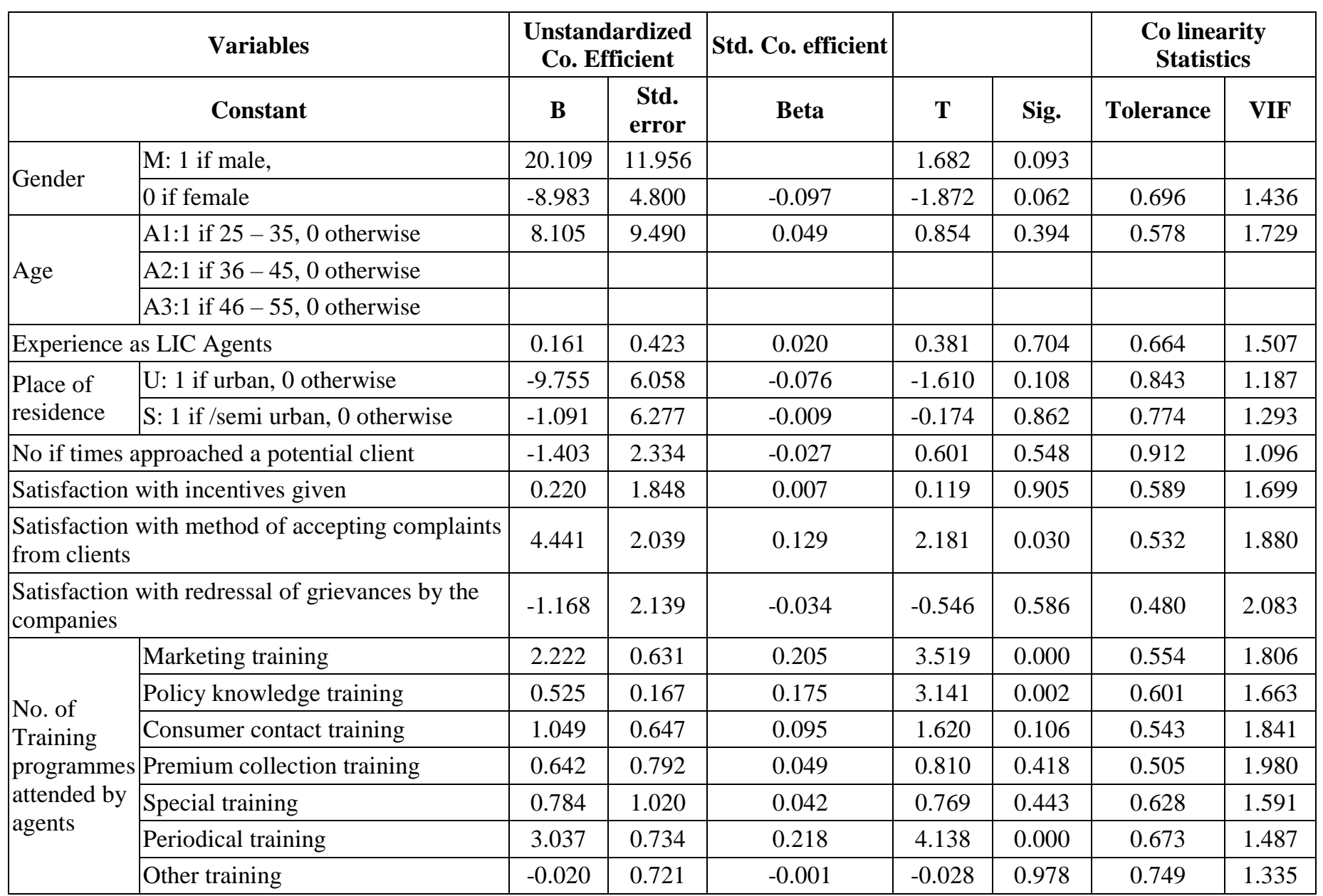

Table.6. Co-efficient of final regression model

\begin{tabular}{|c|c|c|c|c|c|c|c|}
\hline & \multicolumn{2}{|c|}{ Unstandardized Co. Efficient } & \multicolumn{2}{c|}{$\begin{array}{c}\text { Std. Co. } \\
\text { efficient }\end{array}$} & \multicolumn{2}{c|}{$\begin{array}{c}\text { Co linearity } \\
\text { Statistics }\end{array}$} \\
\hline Constant & B & Std. error & Beta & T & Sig. & Tolerance & VIF \\
\hline Satisfaction of agents with method of accepting & 9.258 & 5.208 & 0.020 & 1.778 & 0.076 & & \\
\hline Complaints from policyholders & 3.090 & 1.511 & 0.090 & 5.046 & 0.041 & 0.969 & 1.032 \\
\hline Number training marketing training & 2.828 & 0.496 & 0.261 & 5.705 & 0.000 & 0.901 & 1.110 \\
\hline Attended by agents periodical training & 3.608 & 0.629 & 0.259 & 5.738 & 0.000 & 0.919 & 1.088 \\
\hline Policy knowledge training & 0.612 & 0.131 & 0.205 & 4.663 & 0.000 & 0.976 & 1.024 \\
\hline
\end{tabular}

The Table.5 presents co-efficient of initial regression model. From the Table.5, it can be seen that four independent variables have significant effect on the number of policyholders of the agents. The backward selection method eliminated 16 insignificant variables and the co-efficient of final regression model is shown in Table.6.

The Table. 6 shows that four independent variables have significant effect on the number of policyholders held by the agents. The results indicate that satisfaction of the agents with the method of accepting complaints from the policyholders is positive and is equal to 3.090. It denotes when one unit in the level of satisfaction with the method of accepting complaints increases, there will be an increase of 3.090 policyholders for the agents; similarly, when the number of periodic training attended by the agents increases by one, the policyholders held by the agents increases by 3.608. Also additional marketing training and policy hold by the agents. Multi-collinearity was checked among independent variables using VIF and tolerance estimates.

\section{SUGGESTIONS AND CONCLUSION}

Findings of the study reveal policyholders' expectation of improved service of micro insurance agents, better risk coverage, and affordable amount of insurance premium-so that their intention of switching over to other insurance companies will be stalled. The performance of multiple regression analysis reveals the variables method of accepting complaints from policyholders, and number of training programmes attended by the insurance 
agents in marketing, policy knowledge and periodical training tend to cause variation in the policyholders' strength of the agents. Hence, it is suggested that for improving the purchase of micro insurance policy, the managements of insurance companies should lay down judicious procedures to accept complaints from policyholders. Measures may be devised to reinforce marketing training, policy knowledge training and periodical training programmes of the insurance agents. Micro insurance provides insurance cover to the underprivileged. As a sizeable segment of the population in the study district is poor, illiterate and unorganized, it is imperative on the part of micro insurance companies to cover the entire low income group by promoting investment in micro insurance policy.

\section{REFERENCES}

[1] Ito Seiro and Kono Hiaki, "Why is the take up of Micro Insurance is so Low? Evidence from a Health Insurance
Scheme in India", The Developing Economics, Vol. 48, No. 1, pp. 74-101, 2010.

[2] N. Majumdar, "How to Increase Life Insurance Penetration in the Next Decade", Proceedings of $55^{\text {th }}$ Annual Conference of Insurance Institute of India, pp. 12-16, 2010.

[3] Mrinalini Shah and Shweta Dixit, "Distribution Channels for Incumbent Rural Insurance Industry Confidence", Journal of Risk and Insurance, Vol. 6, No. 3-4, pp. 76-81, 2009.

[4] K. Murali, "Beyond the Horizon-Whacky and Weird Insurance Policies", Insurance Regulatory and Development Authority of India Journal, Vol. 9, No. 2, pp. 37-39, 2011.

[5] B. Ramachandra Reddy, M. Gurumohan Reddy and E. Lavanya, "Role of Micro Insurance in Agriculture", The Insurance Times, Vol. 31, No.12, pp. 21-27, 2011.

[6] Jeyaseelan, "Micro Insurance for the Bottom of the Pyramid Market in India-the way forward", Available at: http://www.docstoc.com/docs/26246380, Accessed on 2014. 